\title{
KECERNAAN JERAMI PADI FERMENTASI DENGAN PROBIOTIK STARBIO PADA DOMBA JANTAN LOKAL
}

\author{
(The Digestibility of Rice Straw Fermented by Probiotic Starbio to Local Male Sheep) \\ Gema Pirngadi Gultom ${ }^{1}$, Tri Hesti Wahyuni ${ }^{2}$, Nevy Diana Hanafi ${ }^{2}$ \\ 1 Mahasiswa Program Studi Peternakan Fakultas Pertanian Universitas Sumatera Utara \\ 2 Staf Pengajar Program Studi Peternakan Fakultas Pertanian Universitas Sumatera Utara
}

\begin{abstract}
This study aimed to determine the effect of the level of utilization of rice straw fermented with probiotic Starbio the digestibility of dry matter and organic matter by local sheep ram.The experiment use 4 local sheep ram with initial body weight $11,87 \pm 1,98 \mathrm{~kg}$.The experiment design used in this study is a Latin square design with 4 treatments. Treatment consists of P0 (unfermented rice straw), P1 $(0.4 \mathrm{~kg}+0.4 \mathrm{~kg}$ urea Starbio/ $100 \mathrm{~kg}$ rice straw), P2 $(0.6 \mathrm{~kg}+0.6 \mathrm{~kg}$ urea Starbio/ $100 \mathrm{~kg}$ rice straw) and P3 $(0.8 \mathrm{~kg}+0.8 \mathrm{~kg}$ urea Starbio/ $100 \mathrm{~kg}$ rice straw $)$. The results showed that the average consumption of dry matter ( $\mathrm{g} / \mathrm{head} /$ day) $(467.06 ; 465.72 ; 489.52$ and 481.1, respectively). Average consumption of organic matter (g/head / day) (391.49; 391.05; 412.92 and 403.65, respectively). Average dry matter digestibility $47.57 ; 46.59 ; 50.07$ and 49.17 , respectively). Average organic matter digestibility 57,$06 ; 56,69 ; 59,85$ and 58,12 , respectively). Based on the result, the using of the starbio until level 0,8 $\mathrm{kg}$ give no significantly different $(\mathrm{P}>0,05)$ on consumption of dry matter, consumption of organic matter, digestibility of dry matter and digestibility of organic matter on local sheep ram.
\end{abstract}

Keywords: Sheep ram, fermentation, rice straw and digestibility

\begin{abstract}
ABSTRAK
Penelitian ini bertujuan untuk mengetahui pengaruh level pemanfaatan jerami padi fermentasi dengan probiotik Starbio terhadap kecernaan bahan kering dan kecernaan bahan organik domba jantan lokal. Penelitian ini menggunakan 4 ekor domba jantan lokal dengan bobot awal 11,87 $\pm 1,98 \mathrm{~kg}$. Rancangan yang digunakan dalam penelitian ini adalah rancangan bujur sangkar latin dengan 4 perlakuan. Perlakuan terdiri atas P0 (jerami padi tanpa fermentasi), P1(0,4 kg Starbio + 0,4 kg urea/ $100 \mathrm{~kg}$ jerami padi), P2 (0,6 kg Starbio + 0,6 kg urea/ $100 \mathrm{~kg}$ jerami padi) dan P3 (0,8 kg Starbio $+0,8 \mathrm{~kg}$ urea/ $100 \mathrm{~kg}$ jerami padi). Hasil penelitian menunjukkan rataan konsumsi bahan kering (g/ekor/hari) 467,06; 465,72; 489,52 dan 481,1. Rataan konsumsi bahan organik (g/ekor/hari) 391,49; 391,05; 412,92 dan 403,65. Rataan kecernaan bahan kering 47,57; 46,59; 50,07 dan 49,17. Rataan kecernaan bahan organik 57,06; 56,69;59,85 dan 58,12. Berdasarkan hasil penelitian penggunaan Starbio sampai level $0,8 \mathrm{~kg}$ tidak memberikan pengaruh yang nyata terhadap konsumsi bahan kering dan bahan organik serta kecernaan bahan kering dan bahan organik pada domba jantan lokal.
\end{abstract}

Kata kunci: Domba, fermentasi, jerami padi dan kecernaan

\section{PENDAHULUAN}

Pakan merupakan salah satu faktor utama yang mempengaruhi sukses tidaknya usaha peternakan domba. Salah satu upaya dalam pengadaan pakan bagi ternak adalah memanfaatkan seoptimal mungkin lahan serta pemanfaatan limbah dan hasil samping komoditi pertanian. Hal ini tidak terlepas dari semakin sulitnya memperoleh hijauan pakan ternak karena semakin banyaknya usaha peternakan domba yang berdiri.Domba di Sumatera Utara pada tahun 2001 
mempunyai populasi 199,3 ribu ekor dengan pemotongan 13,8 ribu ekor.Pada tahun 2009 di Indonesia populasi domba sebanyak 10.199 .000 ekor atau sekitar $24,76 \%$ dari total pupulasi ternak ruminansia di Indonesia. Populasi domba terbesar terdapat di daerah Jawa Barat, Jawa Tengah dan Jawa Timur yaitu berturut-turut 5.311.836; 2.083 .431 dan 729.721 ekor (DITJENNAK, 2010).

Jerami padi merupakan salah satu komoditas pertanian yang paling banyak dimanfaatkan sebagai pakan dan terdapat hampir diseluruh daerah di Indonesia. Per 1 ha sawah menghasilkan kira-kira 5 ton jerami dan 1 ton sekam. Secara keseluruhan, luas lahan padi Indonesia sekitar 12,87 juta ha (Tahun 2010) sama dengan 64,35 ton jerami padi (BPS, 2007). Pemanfaatan limbah pertanian di waktu mendatang akan semakin beragam, tidak hanya untuk digunakan sebagai pupuk tetapi juga sebagai bahan baku industri pengolahan serta industri pakan ternak. Hal ini dapat dilihat dari diversifikasi pemanfaatan produk samping (by product) yang sering dianggap sebagai limbah (waste product) dari kegiatan agroindustri yang berasal dari limbah pertanian menjadi pakan ternak. Sementara itu potensi limbah pertanian dan limbah agroindustri untuk bahan baku pakan cukup melimpah dan belum dimanfaatkan secara optimal. Sebagian besar limbah-limbah tersebut digunakan sebagai bahan bakar, pupuk organik dan bahan baku industri dan sebagian besar masih dibuang atau dibakar.

Penggunaan jerami sebagai bahan pakan mempunyai beberapa kriteria yang tidak diinginkan yaitu mempunyai kandungan protein kasar, $\mathrm{Ca}$ dan $\mathrm{P}$ yangrendah masing-masing adalah $3-5 \%, 0,15 \%$ dan $0,10 \%$ serta kandungan serat kasar yang tinggi $(31,50-46,5 \%)$ akibatnya menimbulkan kecernaan yang rendah yaitu $30-35 \%$ (Komar, 1984). Jerami padi sebagai pakan ruminansia yang potensial untuk mengatasi keterbatasan hijauan. Akan tetapi nutrisi dan kecernaan jerami padi yang rendah serta kandungan silika dan lignin yang tinggi membutuhkan suplementasi protein dan energi dalam penggunaannya sebagai pakan.

Optimalisasi pemanfaatan jerami padi sebagai pakan ternak salah satunya adalah dengan fermentasi menggunakan probiotik Starbio yang bertujuan untuk meningkatkan populasi mikroba di dalam tubuh ternak sehingga daya cerna jerami padi juga dapat meningkat. Starbio merupakan probiotik padat yang mengandung sebagian besar bakteri yang menguntungkan bagi pertumbuhan dan produksi ternak. 


\title{
BAHAN DAN METODE
}

\section{Lokasi dan Waktu Penelitian}

Penelitian dilaksanakan di Laboratorium Biologi Ternak Program Studi Peternakan Fakultas Pertanian Universitas Sumatera Utara. Penelitian ini berlangsung selama 5 bulan dimulai dari 30 April sampai dengan 2 Oktober 2012.

\section{Bahan dan Alat Penelitian \\ Bahan}

Bahan yang digunakan yaitu domba jantan lokal sebanyak 4 ekor dengan bobot awal $11,87 \pm 1,98 \mathrm{~kg}$, pakan konsentrat yang terdiri dari bungkil inti sawit, onggok, daun singkong, dedak padi, molases, urea, mineral mix dan garam. Jerami padi sebagai pengganti pakan rumput, probiotik Starbio sebagai fermentator, kalbazen sebagai obat cacing, rodalon untuk desinfektan dan air minum diberikan secara ad libitum. Kandungan nutrisi raansum tersaji pada Tabel 1.

\begin{abstract}
Alat
Alat yang digunakan yaitu kandang individual 4 unit dengan ukuran 1 x $0,5 \mathrm{~m}$ beserta perlengkapannya, tempat pakan dan minum, timbangan untuk menimbang bobot hidup berkapasitas $50 \mathrm{~kg}$ dengan kepekaan $2 \mathrm{~kg}$, timbangan berkapasitas $2 \mathrm{~kg}$ dengan kepekaan $10 \mathrm{~g}$ untuk menimbang pakan, grinder digunakan untuk menghaluskan bahan pakan konsentrat, termometer digunakan untuk mengetahui suhu di dalam dan di luar kandang, alat penerangan kandang, alat pembersih kandang dan alat tulis untuk menulis data.
\end{abstract}

\section{Metode Penelitian}

Metode penelitian yang digunakan adalah rancangan bujur sangkar latin (RBSL) yang terdiri dari 4 perlakuan. Ransum perlakuan yang diberikan adalah sebagai berikut:

P0: Konsentrat + Jerami padi tanpa fermentasi

$\mathrm{P} 1$ : Konsentrat $+0,4 \mathrm{~kg}$ Starbio $+0,4 \mathrm{~kg}$ urea $100 \mathrm{~kg}$ jerami padi

$\mathrm{P} 2$ : Konsentrat $+0,6 \mathrm{~kg}$ Starbio $+0,6 \mathrm{~kg}$ urea $/ 100 \mathrm{~kg}$ jerami padi

P3: Konsentrat $+0,8 \mathrm{~kg}$ Starbio $+0,8 \mathrm{~kg}$ urea/ $100 \mathrm{~kg}$ jerami padi 


\section{Model RBSL}

$$
\text { Yijk }=\mu+\mathrm{Ti}+\mathrm{Bj}+\mathrm{Kk}+\sum \mathrm{ijk}
$$

Keterangan:

Yijk : respon pengamatan dari perlakuan ke-1, baris ke-j dan kolom ke-k

$\mu \quad$ : nilai tengah umum

$\mathrm{Ti} \quad$ : pengaruh perlakuan ke-i

$\mathrm{Bj} \quad$ : pengaruh baris ke-j

$\mathrm{Kk} \quad$ : pengaruh kolom ke-k

$\sum \mathrm{ijk} \quad$ : pengaruh galat atau sisa karena perlakuan ke-i, baris ke-j dankolom ke-k

Tabel 1. Formulasi konsentrat selama penelitian

\begin{tabular}{llrrrrr}
\hline & Bahan & \% Bahan & \% PK & \%SK & \%LK & \%TDN \\
\hline 1 & BIS & 30 & 4,62 & 4,275 & 0,69 & 21,9 \\
2 & Onggok & 20 & 0,24 & 2,2 & 0,04 & 14,82 \\
& T. D. & & & & & \\
3 & Singkong & 10 & 2,484 & 2,382 & 0,714 & 9,05 \\
4 & Dedak & 33 & 3,795 & 4,9401 & 2,97 & 19,8 \\
5 & Garam & 1 & 0 & 0 & 0 & 0 \\
6 & Urea & 2 & 5,6 & 0 & 0 & 0 \\
7 & Mineral & 1 & 0 & 0 & 0 & 0 \\
8 & Molase & 3 & 0,12 & 0,0114 & 0,0024 & 2,55 \\
\hline & Total & 100 & 16,859 & 13,8085 & 4,4164 & 68,12 \\
\hline
\end{tabular}

\section{Parameter Penelitian}

\section{Kecernaan Bahan Kering (KcBK)}

Kecernaan bahan kering didapatkan dengan cara mengurangi bahan kering konsumsi dengan bahan kering feses lalu dibagi dengan bahan kering konsumsi yang kemudian dikali seratus persen. Bahan kering konsumsi didasarkan pada hasil analisis proksimat dan bahan kering feses diukur dari hasil rata-rata pengukuran bahan kering feses selama tujuh hari terakhir setiap periode penelitian. Koefisien cerna bahan kering dihitung dengan menggunakan rumus:

$$
\mathrm{KcBK}=\underline{(\text { Konsumsi BK }- \text { Pengeluaran BK })} \times 100 \%
$$

Konsumsi BK 


\section{Kecernaan Bahan Organik (KcBO)}

Kecernaan bahan organik didapatkan dengan cara mengurangi bahan organik konsumsi dengan bahan organik feses lalu dibagi dengan bahan organik konsumsi yang kemudian dikali seratus persen. Bahan organik konsumsi didasarkan pada hasil analisis proksimat dan bahan organik feses diukur dari hasil rata-rata pengukuran bahan organik feses selama tujuh hari terakhir setiap periode penelitian. Koefisien cerna bahan organik dihitung dengan menggunakan rumus:

$$
\mathrm{KcBO}=\frac{(\text { Konsumsi BO }- \text { Pengeluaran BO })}{\text { Konsumsi BO }} \times 100 \%
$$

\section{Metode Pengambilan Sampel}

Pengambilan sampel dilakukan pada minggu terakhir dari setiap periode. Pengumpulan total feses dilakukan setiap hari selama satu minggu dimana berat feses ditimbang setiap hari.Dengan cara sebagai berikut :

1. Pengambilan sampel feses dilakukan dengan cara mengoleksi total feses yang diekskresikan setiap hari (24 jam) kemudian ditampung dalam tempat penampungan

2. Pada akhir koleksi feses ditimbang untuk mengetahui berat totalnya

3. Seluruh feses di homogenkan dengan cara diaduk hingga merata

4. Diambil $10 \%$ dari berat total feses dan digiling

5. Dilakukan analisis proksimat dalam feses di Laboratorium

\section{HASIL DAN PEMBAHASAN}

Hasil penelitian tentang pemanfaatan jerami padi fermentasi dengan probiotok Starbio terhadap kecernaan domba jantan lokal dapat dilihat pada Tabel 3.

Tabel 3. Rekapitulasi hasil penelitian pemanfaatan jerami padi fermentasi dengan probiotik Starbio terhadap kecernaan bahan kering dan kecernaan bahan organik domba jantan lokal

\begin{tabular}{ccccc}
\hline Perlakuan & $\begin{array}{c}\text { Konsumsi BK } \\
\text { (g/ekor/hari) }^{\text {tn }}\end{array}$ & $\begin{array}{c}\text { Konsumsi BO } \\
(\mathrm{g} / \text { ekor/hari) }\end{array}$ & $\begin{array}{c}\text { KcBK } \\
(\%)^{\text {tn }}\end{array}$ & $\begin{array}{c}\text { KcBO } \\
(\%)^{\text {tn }}\end{array}$ \\
\hline P0 & $467,06 \pm 23,89$ & $391,49 \pm 20,03$ & 47,57 & 57,06 \\
P1 & $465,72 \pm 43,23$ & $391,05 \pm 36,97$ & 46,59 & 56,69 \\
P2 & $489,52 \pm 36,05$ & $412,92 \pm 30,32$ & 50,07 & 59,85 \\
P3 & $481,11 \pm 19,04$ & $403,65 \pm 15,57$ & 49,17 & 58,12 \\
\hline
\end{tabular}

Ket. $\mathrm{tn}=$ tidak berbeda nyata 


\section{Kecernaan Bahan Kering (KcBK)}

Konsumsi bahan kering domba jantan lokal dihitung dari total konsumsi jerami padi dan konsentrat yang diberikan dan dihitung berdasarkan kandungan bahan keringnya. Pengambilan data konsumsi bahan kering diambil selama 7 hari terakhir dari masa pemeliharaan domba jantan lokal.Rataan kecernaan bahan kering setiap perlakuan selama penelitian dapat dilihat pada Tabel 3.Berdasarkan Tabel 3 rataan kecernaan bahan kering tertinggi terdapat pada perlakuan $\mathrm{P}_{2}$ (Konsentrat + 0,6 kg Starbio $+0,6 \mathrm{~kg}$ urea/100 kg jerami padi) sebesar 489,52 g/ekor/hari, sedangkan rataan kecernaan bahan kering terendah terdapat pada perlakuan $\mathrm{P}_{1}$ (Konsentrat $+0,4$ $\mathrm{kg}$ Starbio $+0,4 \mathrm{~kg}$ urea/100 $\mathrm{kg}$ jerami padi) sebesar 465,72 g/ekor/hari.

Secara pengamatan dapat diketahui bahwa pemberian berbagai level Starbio $(0,4,0,6$ dan $0,8)$ pada jerami padi yang difermentasi memberikan pengaruh yang tidak berbeda nyata $(\mathrm{P}>0,05)$ terhadap konsumsi bahan kering domba. Sekalipun level penggunaan jerami padi fermentasi dengan probiotik Starbio dari keempat perlakuan berbeda tetapi tetap saja memberikan hasil yang sama terhadap konsumsi pakan domba, hal ini dikarenakan kandungan nutrisi dari keempat pakan perlakuan yang dapat dikatakan sama.Tingkat palatabilitas keempat pakan perlakuan inilah yang mempengaruhi ternak dalam mengkonsumsi pakan yang diberikan. Sesuai dengan pernyataan Lubis (1993), yang menyatakan bahwa konsumsi bahan kering (BK) dipengaruhi olehbeberapa hal diantaranya : 1) Faktor pakan, meliputi daya cerna dan palatabilitas 2) faktor ternak yang meliputi bangsa, jenis kelamin, umur dan kondisikesehatan ternak. Hal ini juga sesuai dengan pernyataan Parakkasi (1995), yang juga menyatakan bahwa palatabilitas pakan merupakan salah satu faktor yang mempengaruhi jumlah konsumsi pakan.

Hasil penelitian diketahui bahwa penggunaan berbagai level jerami padi yang difermentasi dengan probiotik Starbio memperoleh rataan konsumsi bahan kering pakan tertinggi terdapat pada perlakuan $\mathrm{P}_{2}$ yaitu (Konsentrat $+0,6 \mathrm{~kg}$ Starbio $+0,6 \mathrm{~kg}$ urea/ $100 \mathrm{~kg}$ jerami padi), bila dibandingkan dengan $\mathrm{P}_{1}$ yaitu (Konsentrat $+0,4 \mathrm{~kg}$ Starbio $+0,4 \mathrm{~kg}$ urea/ $100 \mathrm{~kg}$ jerami padi). Hal ini dikarenakan pakan perlakuan $\mathrm{P}_{2}$ dengan kandungan nutrisi yang tinggi menghasilkan palatabilitas yang baik pula. Sesuai dengan pernyataanParakkasi (1999) yang menyatakan bahwaketersediaan zat makanan yang terpenuhi dari pemberian konsentrat dibutuhkan oleh mikroorganisme di dalam rumen domba untuk menjalankan fungsi dalam membantu proses pencernaan domba. Menurut Anggorodi (1994) umur ternak, kemampuan 
mikroba rumen mencerna pakan, jenis ternak, serta kondisi lingkungan seperti derajat keasaman (pH), suhu dan udara juga dapat menentukan nilai kecernaan,

Berdasarkan hasil penelitian ini dapat dilihat bahwa pemberian berbagai level Starbio pada jerami padi fermentasi dengan probiotik Starbio menghasilkan kecernaan bahan kering sebesar 46,59 - 50,07\%. Hal ini sesuai dengan pernyataan Henson and Maiga (1997) yangmenyatakan bahwa pemberian konsentrat yang mengandung nutrisi yang lengkap akan mengaktifkan mikroba rumen sehingga meningkatkanjumlah bakteri proteolitik dan naiknya deaminasi yang mengakibatkan meningkatnya nilai cerna pakan. Didukung juga oleh Apriyadi (1999) yang menyatakan bahwa tinggi rendahnya kecernaan zat - zat makanan pada ternak bergantung aktivitas mikroorganisme yang berada dalam tubuh ternak. Mikroorganisme ini berfungsi dalam mencerna serat kasar yaitu sebagai pencerna selulosa juga hemiselulosa dan pati.

\section{Kecernaan Bahan Organik (KcBO)}

Kecernaan bahan organik pakan pada domba jantan lokal dihitung dari selisih konsumsi bahan organik pakan pada domba yang dikurangi dengan feses domba (dalam bahan organik) yang dikeluarkan dibandingkan dengan konsumsi bahan organik domba. Kandungan bahan organik pakan yang tinggi disebabkan dari pemberian konsentrat pada domba jantan lokal dan berdampak pada koefisien cerna bahan organiknya yang semakin tinggi. Hal ini berhubungan dengan meningkatnya kandungan mikroorganisme yang menyebabkan tingginya daya cerna pakan. Domba yang mendapatkan jerami padi fermentasi seperti pada perlakuan $\mathrm{P}_{2}$ nilai kecernaannya lebih tinggi dibandingkan dengan perlakuan $\mathrm{P}_{3}$. Disini terlihat bahwa konsumsi bahan organik berbanding lurus dengan kecernaan bahan organik. Menurut Tillman et al. (1991), beberapa hal yang mempengaruhi daya cerna adalah komposisi pakan, jenis ternak, umur ternak dan lingkungan. Pakan dengan kandungan nutrisi yang lengkap akan meningkatkan daya cerna pakan itu sendiri. Sebaliknya, pakan dengan kualitas yang buruk akan berdampak terhadap daya cerna yang semakin rendah.

Rataan kecernaan bahan organik setiap perlakuan selama penelitian dapat dilihat pada Tabel 3. Rataan konsumsi bahan organik pakan pada domba jantan lokal tertinggi diperoleh pada perlakuan $\mathrm{P}_{2}$ sebesar 412,92 g/ekor/hari dan konsumsi bahan organik terendah diperoleh pada perlakuan $\mathrm{P}_{1}$ sebesar 391,05 g/ekor/hari. 
Secara pengamatan dapat diketahui bahwa pemberian berbagai level jerami padi yang difermentasi dengan probiotik Starbio memberikan hasil yang tidak berbeda nyata $(\mathrm{P}>0,05)$ terhadap konsumsi bahan organik domba jantan lokal. Hal ini sejalan dengan hasil analisis ragam konsumsi bahan kering pakan yang juga menunjukkan hasil yang tidak berbeda nyata $(\mathrm{P}>0,05)$, ini dikarenakan pola konsumsi bahan organik mengikuti pola konsumsi bahan kering.

Pemberian berbagi level Starbio pada jerami padi yang difermentasi menghasilkan konsumsi bahan organik tertinggi terletak pada $\mathrm{P}_{2}$ hal ini dikarenakan konsumsi bahan kering yang tinggi dan kandungan abu yang rendah menghasilkan konsumsi bahan organik yang tinggi, begitu juga sebaliknya. Berdasarkan hasil penelitian dapat disimpulkan bahwa pemberian jerami padi fermentasi dengan probiotik Starbio yang lebih cenderung sampai dengan level 0,6 karena menghasilkan konsumsi bahan kering dan bahan organik tertinggi. Hal ini sejalan dengan pernyataan Parakkasi (1995) yang menyatakan bahwa kulitas pakan sangat mempengaruhi fungsi akhir kerja mikroba rumen dalam pemenuhan energinya dalam merombak pakan. Kualitas pakan yang baik akan menghasilkan konsumsi pakan yang tinggi dan dapat meningkatkan kecernaan yang tinggi.

\section{KESIMPULAN}

Fermentasi jerami padi dengan probiotik Starbio tidak mempengaruhi kecernaan bahan kering dan kecernaan bahan organik pada domba jantan lokal.

\section{DAFTAR PUSTAKA}

Anggorodi, R. 1994. Ilmu Makanan Ternak Umum. Gramedia. Jakarta.

Apriyadi, R. 1999. Pengaruh Penambahan Probiotik Bioplus Serat (BS) pada Konsumsi dan Kecernaan Ransum Rumput Gajah (Pennisetum purpureum) yang Diberikan pada Domba Ekor Tipis (DET). Skripsi. Fakultas Pertanian, Jurusan Peternakan. Universitas Djuanda Bogor.

Badan Pusat Statistik Sumatera Utara. 2007. Statistika Indonesia. Biro Pusat Dirjen Peternakan, 2010. Sensus Populasi Ternak Domba. Departemen Pertanian RI. Jakarta. Henson, S., and Maiga, A. S. (1997). Balanced Scorecard, Activity Based Costing and Company Performance : An Empirical Approach. Journal of Management Isuue , 21 (2).

Komar, A. 1984. Teknologi Pengolahan Jerami Sebagai Bahan Pakan Ternak. Dian Grahita. Bandung.

Lubis, D. A. 1993. Ilmu Makanan Ternak. Pembangunan. Jakarta.

Parakkasi, A. 1995. Ilmu Nutrisi Makanan Ternak Ruminansia. UI Press. Jakarta. 
Parakassi, A. 1999. Ilmu Makanan Ternak Ruminansia. Cetakan Pertama.UI Press. Jakarta

Tillman, A. D., H. Hartadi., S. Reksohadiprodjo., S. Prawirokusumo dan

S. Lebdosoekojo. 1991. Ilmu Makanan Ternak Dasar. Gadjah Mada University Press. Yogyakarta. 